\title{
Effect of Liberalization on the Performance of Veterinary Medical Services in Nakuru County, Kenya
}

\author{
Peterson Mwangi Njiru ${ }^{1}$, Daniel Onwonga Auka ${ }^{2}$ \\ ${ }^{1}$ Department of Agriculture, Livestock and Fisheries, County Government of Laikipia, Kenya, P.o Box 41-10400 \\ ${ }^{2}$ Department of Business Administration Egerton University, Kenya, P.o. Box 13357, Nakuru
}

\begin{abstract}
This study sought to determine the effect of Liberalization on performance of Veterinary Medical services in Nakuru County,Kenya. The main objective of this study was to evaluate the effect of liberalization on the performance of Veterinary Medical services in Nakuru County. The specific objectives were; to determine the effect of offloading of services, legislation and credit on performance of Veterinary Medical services in Nakuru and lastly to establish the combined effect of offloading, legislation and credit on performance of Veterinary medical services in Nakuru County. A survey research design was adopted for the study. The target population was the 34 private Veterinary medical practitioners in Nakuru County. Data was collected using structured questionnaires which were administered to the Practicing Veterinarians. Data collected was analyzed using means and standard deviation; and presented inform of tables. Inferential statistics using Pearson correlation coefficients were established to help researcher draw various conclusions on the relationship between independent and dependent variable. Multiple regression analysis was used to examine the effect of Liberalization on performance. The results showed that the joined effect of Liberalization factors on performance of veterinary Medical services was significant. Among the independent variables Legislation had biggest relationship with performance and had the strongest contribution to performance. From the study the combined effect of the liberalization factors on performance was quite significant. The research concludes that though Veterinary legislation has the highest contribution to performance, a combination with offloading of functions from the public sector to the private sector and availability of credit would improve performance.
\end{abstract}

Keywords: Liberalization, offloading, credit, legalization, performance and veterinary services

\section{Introduction}

Kenya has a well developed Livestock sector which contributes about $12.5 \%$ to the GDP. However the sector is faced with numerous challenges, among them low productivity due to inadequate availability of Veterinary services. Before attaining independence in 1963 the Department of Veterinary Services used to provide comprehensive public veterinary provision in high potential areas. The services were concentrated in the settler largescale dairy farms and beef ranches, provided by both the public sector and by private foreign veterinarians.

After independence in 1963, the Kenya government expanded the veterinary services to respond to the demand of veterinary services created by changes in land holding, livestock-rearing and the extension of services to the population.

The Government was able to support a high level of public sector delivery due to the prevailing healthy economy and the generosity of various donors. The Government began setting up new veterinary centers in the 1970s staffed by Government veterinary professionals mainly in the high potential dairy areas. The centers provided services either free of charge or at highly subsidized levels, with farmers paying for the drugs but not for the consultation. The government provided free dip services, and also artificial insemination (AI).By mid eighties this of level of subsidy in delivery of services was no longer sustainable and the Kenya Government embarked on Liberalization of services by transferring Artificial insemination, Clinical services and distribution of veterinary inputs to the private sector and sharing some services with the private sector with mixed levels of success. The major impediments to liberalization and privatization of veterinary services has been nonconducive physical environment, high delivery costs due to poor infrastructure, inadequate access to credit, illegal operators, difficult in communication, low cash economy in the rural households, Competition from Government Veterinarians ,inefficient control on drug supply and drug application and cyclic rural instability and displacement of farmers every 5 years due to insecurity during election cycles.

\subsection{Statement of the Problem}

Poor livestock health services remain one of main constraints to livestock production in many developing countries and there is need to identify the existing status and constraints of Animal health service delivery and thus recommending possible alternatives for its sustainable development. Sustainable improvement of animal health service delivery needs increased awareness for all stake holders and a well regulated private service in order to mitigate constraints in service delivery.Previous studies has shown that development of private veterinary services in developing countries has been very slow.In Kenya, liberalization of veterinary services has taken several models depending on ecological zones to improve performance of private veterinary services to its farmers. However, this strategy to improve services is still faced with several challenges with many complaints of; inadequate access to professional veterinary services, increased livestock diseases 


\section{International Journal of Science and Research (IJSR) \\ ISSN (Online): 2319-7064}

Index Copernicus Value (2016): 79.57 | Impact Factor (2015): 6.391

incidences, inadequate supply of veterinary inputs and decline in Artificial inseminations leading to heavy economic losses to farmers due to reduced production. This study therefore sought to investigate the effect of liberalization on performance of veterinary services in Nakuru County, Kenya.

\subsection{Objective of the Study}

The general objective of the study was to evaluate the effect of liberalization on performance of veterinary medical services in Nakuru County. The Specific Objectives of the Study were as follows

1) To determine the effect of Offloading of services on performance of Veterinary Medical services.

2) To determine effect of the Legislation on performance of Veterinary Medical services.

3) To determine the effect of Credit on performance of Veterinary Medical services.

4) To establish the composite effect of liberalization on performance of veterinary Medical services.

\subsection{Research Hypotheses}

This research sought to test the following hypothesis of Veterinary Medical services.

$\mathrm{H}_{0} 1$ Offloading of services has no significant effect on performance of Veterinary Medical services.

$\mathrm{H}_{0} 2$ Legislation has no significant effect on performance of Veterinary Medical services.

$\mathrm{H}_{0} 3$ Credit has no significant effect on performance of Veterinary Medical services.

$\mathrm{H}_{0} 4$ The combined effect of Liberalization factors (legislation, offloading and credit ) do not have a significant effect on performance.

\section{Literature Review}

This study is guided by the privatization theory as embedded in the Coase Theorem. Ronald Coase theorizes that the private sector is effective in solving the problem of externalities, through costless bargaining, driven by individual incentives. According to the Coase Theorem, individual parties will directly or indirectly take part in a cost-benefit analysis, which will eventually result in the most efficient solution (Mankiw,2001).. There are many theoretical economic benefits that are connected to the process of privatization. One of the main reasons why countries pursue liberalization and privatization is in order to reduce the size of the existing government, based on the idea that many governments have become too large and overextended, consisting of unnecessary layers of bureaucracy.

Liberalization can have a positive secondary effect on a country's fiscal situation. As Easterly (2001) discusses, liberalization and privatization should not be used to finance new government expenditures and pay off future debts. Instead, privatization enables countries to pay a portion of their existing debt, thus reducing interest rates and raising the level of investment. By reducing the size of the public sector, the government reduces total expenditure and begins collecting taxes on all the businesses that are now privatized. privatization leads to an increase in foreign direct investment which can potentially play a significant factor in the quest for performance. Foreign investment has "positive spillovers of improved technology, better management skills, and access to international production networks" (World Bank, 2002). Easterly (2001), stresses the importance of the possible benefits from technological improvements as well as the spillover effect created from new innovations. Easterly, presents the theory and examples of how underdeveloped countries might have an advantage over developed countries when it comes to new technology.

According to Poole, (1996) Liberalization, which is a method of reallocating assets and functions from the public sector to the private sector, appears to be a factor that could play a serious role in the quest for performance. In recent history, liberalization /privatization has been adopted by many different political systems and spread to every region of the world (Poole, 1996).

From the above review, the process of Liberalization can be an effective way to bring about fundamental structural change by formalizing and establishing property rights, which directly create strong individual incentives.This chapter has given an insight into the literature by scholars and researchers on studies that are related to the effects of liberalization on performance. It has reviewed the literature that is related to the objectives of this study. In addition the theoretical framework, success stories and a critical review on the major issue and gaps of the past available reviews and results from other researchers in the same field of study are given, also the conceptual framework model is also presented after the review of the literature. Finally, the gaps and conceptual framework is given

Privatization of Veterinary services in Kenya is an old process which was being practiced in commercial farms and ranches up to 1963 when the government took over delivery of the service only to attempt to give it back to the private sector from 1988. However for the strategy to succeed, due to many inherent challenges, National legislation and its effective implementation appear to be one of the solutions to some of the problems which have been variously identified. There is need to reassess existing legislation in Kenya and no doubt this will be a continuing process. To have a way forward on privatization there is need for situation analysis of Animal health delivery systems and then propose appropriate improvement strategy bench marked against best world practices so as to get prevailing problems, weaknesses and constraints hindering privatization (Hubl, et al 1998). Achoja et al (2010) showed that though in Delta state of Nigeria, the veterinary services delivery was structured into public and private sectors majority $(60.9 \%)$ of the commercial poultry farmers demanded and obtained veterinary services from the public sector. However it was concluded that it is much more difficult to encourage private professional practice in ASAL areas (Holden \& Chema, 1996).

The major obstacles to privatization of veterinary services are seen as firstly as non-conducive physical environment, secondly high delivery costs due to poor infrastructure, thirdly lack of appropriate support structures e.g. credit,

\section{Volume 6 Issue 12, December 2017}




\section{International Journal of Science and Research (IJSR) \\ ISSN (Online): 2319-7064}

Index Copernicus Value (2016): 79.57 | Impact Factor (2015): 6.391

fourthly too many illegal operators, fifth difficult in communication, sixth low cash economy, seventh lack of efficient control on drug supply and drug application and lastly displacement of farmers due to insecurity during election cycles. Up to now, where veterinarians have been helped to set up a private practice in the country, this has mainly involved extension of credit from pharmaceutical firms (Turkson \& Brownie 1999).

Unfair competition from Government practice is reported to be a main obstacle to successful private practice. Private Veterinarians may be worried by competition and feel their businesses may be seriously compromised by unfair competition from government veterinarians. The problem is that Government-employed veterinarians sell their services to farmers either within or outside of government hours. As civil servants they have few or no overheads and can easily undercut the fees of the private veterinarian. There is argument that if this is not possible then the activities of state veterinarians should be restricted to regulatory work only (Wamukoya, et al., 1995).

Nearly all veterinary related activities are highly dependent on a regular and assured availability of quality inputs. In many African countries, input procurement and distribution have been a monopoly of the government veterinary services. With the restriction of operational budgets, both procurement and distribution have been limited. This situation has given rise to implementation of cost recovery and revolving funds for both private and public goods and services. These programmes, implemented within the government veterinary services, have met with varying success in terms of equity, sustainability and motivation of public service veterinarians to meet the palpable demands of their public employer versus those of their producer-client (FAO, 1994).

An alternative approach is to liberalize procurement and distribution of inputs through the private sector (Cheneau,1984). Pharmaceutical distributors have generally responded favorably to input liberalization by supporting veterinarians and pharmacists to provide remedies, chemicals, equipment and some vaccines to the public. Experience to date indicates that sales of quality inputs by private providers have increased while availability of substandard inputs has declined.Nonetheless the state should retain ultimate responsibility for oversight of those functions designated as public and should delegate only their execution (Schillhorn and de Haan, 1995; Mehraban et al 1996; Sidahmed, 1995).

The logic and rationale for the creation of each component, as well as assigning specific tasks and responsibilities, are based on economic, biological and social principles (FAO 1997). Thus, improved delivery and assured access to appropriate livestock goods and services including health, husbandry, management and extension advice, are predicted to improve livestock productivity to more economic levels. Schreuder et al. (1995) reported beneficial animal health and financial effects resulting from access to a basic animal health service in southern Afghanistan.. In Africa where agriculture and livestock are so vital to the national economy in many countries, animal health and the delivery of veterinary services have been particularly important components of this process.

Numerous publications have considered the distribution of the different animal health functions performed by the public and private sectors. This is intended as a guide for consideration by governments; it gives functions that could be considered as falling under the responsibility of the private sector, remains under the responsibility of the public sector, or are candidates for shared responsibility and shared execution.

According to Umali and Schwartz (1994) the private sector thrives best in environments without government interference. Encouraging private sector participation implies promoting private sector investment. livestock institutions should focus more clearly on the needs and aspirations of poor people as a central facet of poverty alleviation. This requires institutions to realign current ways of working to ensure that communities are actively involved in the reform of policies and legislation which affect their lives and livestock.

Funding agencies, advisers, and international organizations need to support the change in the role of the public as well as the private veterinary services for privatization to be effected. In most respects, privatization should be seen as a process that refocuses government veterinary activities on achieving better services for the public and not necessarily as a vehicle for reducing the real magnitude of government expenditures and responsibilities (Ilemobade, 1996).

Capital may be available as government loans, governmentbacked bank loans or private capital. Freezing the automatic hiring of all veterinary graduates gives a potent stimulus for the emergence of private veterinary practices, while removal of unfair competition by the public sector is crucial to their early viability . However, private practitioners may offer better concrete access to animal health services even in these conditions, but such an outcome depends critically on the way in which privatization is implemented. Experience to date suggests that government decision-makers need not be too concerned with the availability of credit provided overall enabling policies are in place.providing support to professional veterinarians and commercial enterprises is the main option normally considered as an entry for the process of privatization.

The above stated arguments and others within the literature are all important to liberalization. However none of this studies have emphasized on liberalization and performance with objectives of credit, legislation and offloading of services in consideration. Therefore this study looks at these objectives for the purpose of improvement of performance of veterinary services.

\subsection{Conceptual Framework}

Volume 6 Issue 12, December 2017 www.ijsr.net 
International Journal of Science and Research (IJSR)

ISSN (Online): 2319-7064

Index Copernicus Value (2016): 79.57 | Impact Factor (2015): 6.391

Independent Variable

Liberalization
Offloading of Veterinary Services
- Procurement \&Distribution of drugs and vaccines
- Clinical diagnosis and treatment
- Disease diagnosis and reporting
- Artificial Insemination services
- Management of herd health
Legislation
- Updating legislation
- Registration and regulation of professionals
- Registration and quality control of Drugs
- Compliance and monitoring of Ethics
Credit
- Kenya veterinary Association privatization Scheme
- KVAPS)
- Povernment loans
- Private capital
- Informal credit

Dependent Variable

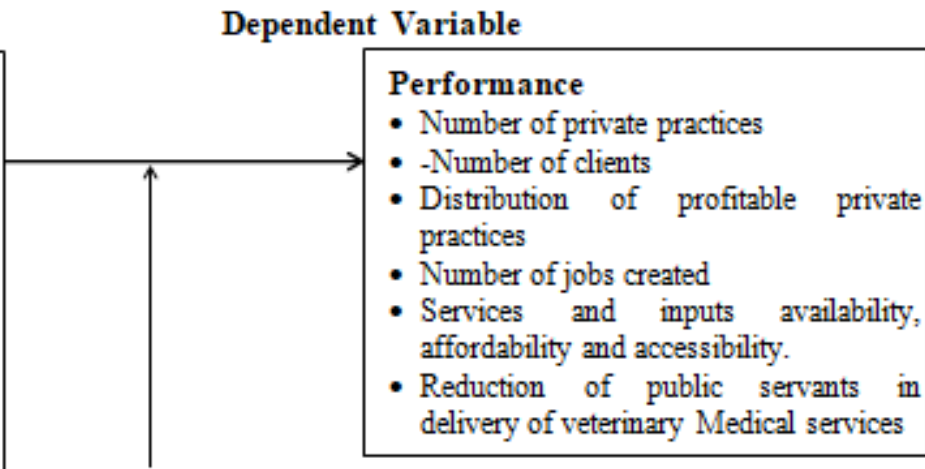

Environmental factors

- Physical environment

- Infrastructure

- Competition by Public sector with the Private sector

- Insecurity

- Cash Economy

\section{Extraneous variables}

Figure 2.1: Relationship between Liberalization, Environmental Factors and performance

Liberalization should be effected through appropriate processes that will allow liberalization to take place through offloading of Veterinary services, legislation, and availability of credit eventually affecting performance of Veterinary Medical services.

The extraneous factors can either slacken or facilitate the liberalization process impacting on performance. Various factors such as non-conducive physical environment, high delivery costs due to poor Infrastructure, difficult in communication unfair Competition by Public sector with the Private sector, insecurity and poor cash Economy are major constraints to liberalization and influencing performance.

\subsection{Research Design}

The study used Survey research design. Data was collected from respondents about their opinions and experiences on liberalization. The population of the study comprised all the 34 Veterinary Medical Practitioners in Nakuru County identified by the County Director of Veterinary services. The Practitioner were located in Naivasha, Bahati, Nakuru town, Njoro, Molo sub counties of Nakuru County, Kenya.

\subsection{Sampling Method}

The use of questionnaires was found to be the most effective and affordable way of collecting information from a small sample within a short time. The unit of analysis was the veterinary practice and data was collected at the Practice. The respondents were the veterinary practitioners running the practice. The study used a five point Likert questionnaire to collect data The questionnaire was explained to the respondents and left to be filled and collected after one week. A follow was made with the respondents for questions that were not understood.

\subsection{Data Analysis}

The data collected from the respondents was recorded, edited, coded and tabulated to ensure completeness and accuracy. Statistical package for social science (SPSS) was used as a tool of analysis. Data that was obtained from the research questionnaire was summarized using descriptive statistics. Pearson's Correlation product was used to test relationships and multiple regression analysis used to test for the effect of each aspect of liberalization on performance.

The study examined three factors in Liberalization which are offloading of veterinary service functions to the private sector, Veterinary services legislation and access to credit and performance of the service. This was done using means and standard deviations.

The results of the analysis of offloading Veterinary services Functions are in this

Mean and Standard Deviations for Measures of offloaded Veterinary services

\begin{tabular}{|c|c|c|c|}
\hline & $\mathrm{N}$ & Mean & $\begin{array}{c}\text { Std. } \\
\text { Deviation }\end{array}$ \\
\hline $\begin{array}{c}\text { Offloading of distribution of drugs and } \\
\text { vaccines by public sector influences } \\
\text { performance }\end{array}$ & 34 & 3.71 & 1.47 \\
\hline $\begin{array}{c}\text { Offloading of clinical diagnosis and } \\
\text { treatment to private sector influences } \\
\text { performance }\end{array}$ & 34 & 3.71 & 1.43 \\
\hline $\begin{array}{c}\text { Offloading of disease diagniosis to } \\
\text { reporting to private sector influences } \\
\text { performance }\end{array}$ & 33 & 3.00 & 1.52 \\
\hline $\begin{array}{c}\text { Offloading of Artificial insemination } \\
\text { services to private sector influences } \\
\text { performance }\end{array}$ & 34 & 3.85 & 1.33 \\
\hline $\begin{array}{c}\text { Offloading herd health management to } \\
\text { private sector influences performance }\end{array}$ & 33 & 3.61 & 1.35 \\
\hline Overall Mean & & $\mathbf{3 . 5 8}$ & \\
\hline
\end{tabular}




\section{International Journal of Science and Research (IJSR) \\ ISSN (Online): 2319-7064}

Index Copernicus Value (2016): 79.57 | Impact Factor (2015): 6.391

As shown in the item of 'offloading with the highest mean score is offloading of Artificial insemination services' $(\mathrm{M}=$ 3.85, Std Dev $=1.33$ ). The item with the lowest mean score is 'offloading of disease diagnosis to reporting to private sector influences performance' $(\mathrm{M}=3.00$, Std. Dev. $=1.52)$. The overall mean for offloading is 3.58. The results are interpreted to mean that the respondents agreed that offloading of veterinary services functions have been offloaded to a great extent.

\section{Veterinary Services Legislation}

The study examined the legal framework of veterinary services to support the private sector. This was done using means and standard deviations.

Mean and Standard Deviations for Measures of Veterinary legislation

\begin{tabular}{|c|c|c|c|}
\hline & $\mathrm{N}$ & Mean & $\begin{array}{c}\text { Std. } \\
\text { Deviation }\end{array}$ \\
\hline Updating legislation & 34 & 3.44 & 1.26 \\
\hline Registration and regulation professionals & 34 & 3.62 & 1.46 \\
\hline Registration and quality control of drugs & 34 & 4.00 & 1.41 \\
\hline $\begin{array}{c}\text { Compliance to monitoring and ethics by } \\
\text { government }\end{array}$ & 34 & 3.50 & 1.35 \\
\hline Overall Mean & & $\mathbf{3 . 6 4}$ & \\
\hline
\end{tabular}

As shown in Table 4.11, the item of 'registration and quality control of drugs influences performance' $(\mathrm{M}=4.00$, Std. Dev. = 1.41). The item with the lowest mean score is 'Updating legislation influences performance' $(\mathrm{M}=3.00$, Std. Dev. = 1.41). The overall mean for veterinary legislation is 3.64. The results are interpreted to mean that the respondents agreed that veterinary services have been legislated to a great extent.

\section{Access to Credit Sources}

The study described the credit sources to veterinary services. This was done using means and standard deviations.

\section{Mean and Standard Deviations for Measures of credit} sources

\begin{tabular}{|l|c|c|c|}
\hline & $\mathrm{N}$ & Mean & Std. Deviation \\
\hline Credit from KVAPS & 33 & 3.39 & 1.27 \\
\hline Loans from government & 34 & 3.15 & 1.40 \\
\hline credit from pharmaceutical firms & 33 & 3.97 & 1.26 \\
\hline
\end{tabular}

\begin{tabular}{|l|c|c|c|}
\hline Private capital sources & 33 & 3.76 & 1.23 \\
\hline Credit from informal sources & 33 & 3.64 & 1.06 \\
\hline Overall Mean & & $\mathbf{3 . 5 8}$ & \\
\hline
\end{tabular}

The results show that the item with the highest score is 'credit from pharmaceutical firms' $(\mathrm{M}=3.97$, Std. Dev. = 1.26). The item with the lowest mean score is 'Loans from government' $(\mathrm{M}=3.15$, Std. Dev. = 1.40). The overall mean for credit sources is 3.58. The results are interpreted to mean that the respondents agreed that they were able to access credit from the sources indicated to a great extent.

\section{Performance Measures}

The study analysed the performance of veterinary medical services. This was done using means and standard deviations.

Mean and Standard Deviations for Measures of performance veterinary medical services

\begin{tabular}{|c|c|c|c|}
\hline & $\mathrm{N}$ & Mean & $\begin{array}{c}\text { Std. } \\
\text { Deviation }\end{array}$ \\
\hline Growth in number of private practices & 34 & 3.71 & 1.59 \\
\hline Number of clients & 33 & 2.97 & 1.45 \\
\hline $\begin{array}{l}\text { Distribution of professional private } \\
\text { practices }\end{array}$ & 34 & 3.26 & 1.29 \\
\hline Increased number of jobs & 34 & 3.24 & 1.42 \\
\hline $\begin{array}{l}\text { Service availability, affordability and } \\
\text { accessibility }\end{array}$ & 34 & 3.38 & 1.28 \\
\hline $\begin{array}{l}\text { Reduction in public servants in } \\
\text { delivery of Veterinary services }\end{array}$ & 34 & 3.50 & 1.21 \\
\hline Overall Mean & & 3.34 & \\
\hline
\end{tabular}

The results indicate that the item with the highest score is 'growth in number of private practices' $(\mathrm{M}=3.71$, Std. Dev. $=1.59$ ). The item with the lowest mean score is 'number of clients' $(M=2.97$, Std. Dev. = 1.45). The overall mean for credit sources is 3.34 . The results are interpreted to mean that the respondents agreed that there was growth in performance of veterinary services.

\section{Hypothesess Testing}

The study examined how the variables of the study; offloading, legislation and credit were related to performance of veterinary Medical services .The analysis was done using Pearson's correlation matrix.

Correlation Matrix for offloading, Legislation, Credit on Performance

\begin{tabular}{|c|c|c|c|c|c|}
\hline & & Offloading & Legislation & Credit & Performance \\
\hline Offloading Of & Pearson Correlation & 1 & $.729^{* *}$ & $.600^{* * *}$ & $.672^{* * *}$ \\
\hline \multirow[t]{2}{*}{ Veterinary Services } & Sig. (2-tailed) & & 0 & 0 & 0 \\
\hline & $\mathrm{N}$ & 34 & 34 & 34 & 34 \\
\hline \multirow[t]{3}{*}{ Legislation } & Pearson Correlation & $.729^{* *}$ & 1 & $.620^{* *}$ & $.723^{* *}$ \\
\hline & Sig. (2-tailed) & 0 & & 0 & 0 \\
\hline & $\mathrm{N}$ & 34 & 34 & 34 & 34 \\
\hline \multirow[t]{3}{*}{ Credit } & Pearson Correlation & $.600^{* *}$ & $.620^{* *}$ & 1 & $.547^{* *}$ \\
\hline & Sig. (2-tailed) & 0 & 0 & & 0.001 \\
\hline & $\mathrm{N}$ & 34 & 34 & 34 & 34 \\
\hline \multirow[t]{3}{*}{ Performance } & Pearson Correlation & $.672^{* *}$ & $.723^{* *}$ & $.547^{* *}$ & 1 \\
\hline & Sig. (2-tailed) & 0 & 0 & 0.001 & \\
\hline & $\mathrm{N}$ & 34 & 34 & 34 & 34 \\
\hline
\end{tabular}




\section{International Journal of Science and Research (IJSR) \\ ISSN (Online): 2319-7064}

Index Copernicus Value (2016): 79.57 | Impact Factor (2015): 6.391

\section{Hypothesis One}

$\mathrm{H}_{0} 1$ : No significant relationship between performance of Veterinary medical services and offloading of veterinary services to private sector in Nakuru County.

The results of the correlation analysis indicate that there was a significant positive relationship between offloading of veterinary services and performance $(r=0.672, \mathrm{p}<$ 0.05). Therefore the decision was to reject null hypothesis. This was because there was enough evidence to support that offloading was related to performance.

FAO (2012), noted that a government's operational capacity and effectiveness can be improved by rationalizing the delivery of public good veterinary services while divesting those services that can be commercialized and that benefit individual owners of livestock which is supported by findings from this study.

\section{Hypothesis Two}

$\mathrm{H}_{0} 1$ : There is no significant relationship between legislation and performance of professional private practices in Nakuru County.

The results of the correlation analysis indicate that there was a significant positive relationship between legislationand performance $(\mathrm{r}=0.723, \mathrm{p}<0.01)$. Therefore the decision was to reject the null hypothesis. This finding is in line with the report by Umali and Schwartz (1994) that the private sector thrives best in environments without government interference. The same report notes that governments can help by creating and ascertaining conditions and regulations that support private initiative and private sector operation.

\section{Hypothesis Three}

$\mathrm{H}_{0} 3$ : There was no significant relationship between performance of Private veterinary Medical services in Nakuru County and availability of credit to the private sector.

The results of the correlation analysis indicate there was a significant positive relationship between availability of credit and performance $(\mathrm{r}=0.547, \mathrm{p}<0)$. Therefore the decision was to reject null hypothesis. This finding is in line with Ahmed, (2004) who observed that providing credit support to professional veterinarians and commercial enterprises is the main option normally considered as an entry for the process of privatization. Typically, a limited amount of loan money is provided to a few veterinarians to support them while they undertake drug purchase and sale and animal treatment practices. An environment of full-cost recovery would be essential for this activity. Otherwise, the private veterinarians may not survive in the business.

\section{Hypothesis four}

$\mathrm{H}_{0} 4$ The liberalization composite initiative has no effect on the performance of professional Private veterinary services in Nakuru County.

The study sought to establish the combined effect of liberalization on performance. According to table 14, R square value was (0.572).The result indicates offloading, legislation and credit had a significant effect on performance. The R square value of (0.572) means that the predictors attributes $57.2 \%$ variability in the domain and $42.8 \%$ is a result chance, error or other variables not discussed in this study. The decision was to reject the null hypothesis since there was a strong relationship between composite effect of offloading, legislation and credit on performance.

Multiple regression
\begin{tabular}{|c|c|c|c|c|}
\hline \multicolumn{5}{|c|}{ Model Summary } \\
\hline Model & R & R Square & Adjusted R Square & $\begin{array}{c}\text { Std. Error of the } \\
\text { Estimate }\end{array}$ \\
\hline 1 & $.757^{\text {a }}$ & 0.572 & 0.53 & 0.72564 \\
\hline \multicolumn{2}{|c|}{ a. Predictors:(Constant), Credit, Offloading, Legislation } \\
\hline
\end{tabular}

ANOVA ${ }^{b}$

\begin{tabular}{|c|c|c|c|c|c|c|}
\hline \multicolumn{2}{|r|}{ Model } & $\begin{array}{l}\text { Sum of } \\
\text { Squares }\end{array}$ & Df & $\begin{array}{l}\text { Mean } \\
\text { Square }\end{array}$ & $\mathrm{F}$ & Sig. \\
\hline \multirow{3}{*}{1} & Regression & 21.148 & 3 & 7.049 & 13.388 & $.000^{\mathrm{a}}$ \\
\hline & Residual & 15.797 & 30 & 0.527 & & \\
\hline & Total & 36.945 & 33 & & & \\
\hline \multicolumn{7}{|c|}{$\begin{array}{l}\text { a. Predictors: (Constant), CREDITINDEX, } \\
\text { OFFLOADINDEX, LEGILINDEX }\end{array}$} \\
\hline \multicolumn{7}{|c|}{ b. Dependent Variable: PERFINDEX } \\
\hline
\end{tabular}

Coefficients $^{\text {a }}$

\begin{tabular}{|c|c|c|c|c|c|c|}
\hline & \multirow{2}{*}{ Model } & \multicolumn{2}{|c|}{$\begin{array}{c}\text { Unstandardized } \\
\text { Coefficients } \\
\end{array}$} & \multirow{2}{*}{$\begin{array}{l}\text { Standardized } \\
\text { Coefficients } \\
\text { Beta }\end{array}$} & \multirow{2}{*}{$\mathrm{T}$} & \multirow{2}{*}{ Sig. } \\
\hline & & B & $\begin{array}{l}\text { Std. } \\
\text { Error }\end{array}$ & & & \\
\hline \multirow{4}{*}{1} & (Constant) & 0.6 & 0.546 & & 1.099 & 0.28 \\
\hline & OFFLOADING & 0.254 & 0.164 & 0.281 & 1.551 & 0.131 \\
\hline & LEGISLATION & 0.393 & 0.158 & 0.459 & 2.485 & 0.019 \\
\hline & CREDIT & 0.115 & 0.194 & 0.094 & 0.592 & 0.558 \\
\hline
\end{tabular}

The ANOVA demonstrates test for the combined effect of the factors of Liberalization on performance of Veterinary medical services. The Anova result show that the model was significant $(\mathrm{F}=13.3888, \mathrm{p}<0.05)$.This indicates that the combined effect of Offloading, legislation and credit had a significant effect on Performance.

The standard coefficients show that the effect of legislation on performance is positive and significant $(\beta=0.459, \mathrm{t}=$ $2.485, \mathrm{p}<0.05)$, the effect of offloading was positive and insignificant $(\beta=.281, \mathrm{t}=1.551, \mathrm{p}>0.05)$, the effect of credit is positive and insignificant $(\beta=0.094, \mathrm{t}=0.594, \mathrm{p}>0.05)$.

This indicates that Legislation has the greatest effect on performance $(\beta=0.459, \mathrm{t}=2.485, \mathrm{p}<0.05)$ with insignificant contribution by offloading and credit sourcing.

This shows that policy makers should prioritize enacting laws and policies that will enable growth of the private sector.

\section{Summary of the Findings}

The first objective was to find out the effect of offloading on performance of Veterinary Medical services. The findings reveal a positive significant relationship between offloading and performance, hence $\mathrm{H}_{0} 1$ was rejected.

\section{Volume 6 Issue 12, December 2017




\section{International Journal of Science and Research (IJSR) \\ ISSN (Online): 2319-7064}

Index Copernicus Value (2016): 79.57 | Impact Factor (2015): 6.391

The second objective of the study was to determine the effect of legislation on performance of Veterinary Medical services; the findings indicate a strong positive relationship between legislation and performance. Therefore $\mathrm{H}_{0} 2$ was rejected.

The third objective of the study was to determine the effect of credit on performance of Veterinary Medical services. The findings of the study show a positive relationship between credit and performance. Therefore $\mathrm{H}_{0} 3$ was rejected.

The fourth objective of the study was to determine the combined effect of offloading, legislation and credit on performance. The hypothesis was tested using multiple regression analysis indicating that the combination of the variables contributed only $57.2 \%$ to performance. Hence there are more factors contributing $48.2 \%$. Therefore $\mathrm{H}_{0} 3$ is partially rejected.

From this analysis Legislation has the greatest effect on performance followed by offloading with Credit having the least effect

\section{Conclusion}

The study has revealed that the process of liberalization contributes to performance. It can be concluded that a strong link between legislation and performance of veterinary medical services and that legislation is the highest contributor to performance. This therefore implies that continuous updating of existing legislation will create an enabling environment for all practitioners with improved performance, compliance and monitoring of ethics will ensure that there is a level playing ground that will remove unqualified people from practice. Registration and regulation of professionals will ensure that practitioners are closely monitored hence ethical conduct to avoid professional sanctions. Registration and quality control of drugs will ensure that there will be no unfair competition in the market from substandard products.

The results also showed that offloading through procurement and Distribution of drugs and vaccines, disease and clinical diagnosis, treatment, Artificial insemination services, management and reporting of herd health is crucial for performance. From the findings of this study these are services that have over time been carried out by the public sector and continuous offloading will lead to improved performance.

The study also found that credit to Veterinary practitioners from the Kenya privatization scheme, government, Pharmaceutical companies, private capital and informal sources are necessary for improved performance. However the contribution of credit is insignificant

Finally, the combined effect of legislation Offloading and credit when put into consideration results to an increase in: available, affordable, accessible services and inputs, the number and distribution of profitable private practices, employment rates; and reduced over reliance on public servants.
This study shows that policy makers should prioritize providing an enabling environment by enacting necessary legislation to improve performance.

\section{Recommendations of the Study}

The study was done to determine the effect of offloading of various veterinary services provided by public sector to the private sector, effect of various legislative factors that affect performance and effect of the various credit sources on performance. The Study also determined the combined effect of the three Liberalization factors on performance. The findings of the study conducted in Nakuru County have various implications on public policy direction as expounded below.

\section{Recommendations for Policy and Practice}

This study has implications on policy and Practice. First the study confirmed a positive relationship between legislation and performance. This implies that legislative issues are essential for increased performance. Policy makers should therefore carry out situation analysis on all legislative issues that contribute to the liberalization process to encourage more participation of the private sector in delivery of services so as to improve performance. In addition, the public sector should be encouraged to continuously transfer more functions still held as public good to the private sector. This will enable more practitioners to take up private practice hence strongly influencing delivery of Veterinary medical services. With adequate enabling legislation and more functions transferred to the private sector, credit sources will be more attractive to private practitioners with improved performance of services.

Lastly the results show that the joint effect of Legislation, offloading of functions to the private sector and availability of credit has a lesser impact on performance than legislation on alone. This implies that to enhance performance, policy makers need to concentrate on a legal framework that creates an enabling environment to improve performance.

\section{Recommendation for Further Study}

Since the study findings reveal that the combined effect of legislation, offloading and credit contribute to only $57.2 \%$ on performance, its therefore necessary that future research examines the effects of other factors such as competition, infrastructure, physical environment, insecurity and cash economy identified in the literature which may be contributing to the remaining $42.8 \%$ of the performance of veterinary Medical services. It is also recommended that other research studies on performance of Veterinary services should be carried out among farmers and other beneficiaries of Veterinary services for a more inclusive analysis.

\section{References}

[1] Angniman,P.A,(1996).Privatization of veterinary services within the context of structural adjustment in Mali, Cameroon and Chad. Rome, FAO. 


\section{International Journal of Science and Research (IJSR) \\ ISSN (Online): 2319-7064}

Index Copernicus Value (2016): 79.57 | Impact Factor (2015): 6.391

[2] Ashley, S.D., Holden, S.J. \& Bazeley, P.B.S, (1996).The changing role of veterinary services: a report of a survey of chief veterinary officers' opinions. Somerset, UK, Livestock in Development.

[3] Belsley, D.A.,Kuh,e., \& Welsch, R. E (1980) Regression diagnostic: Identifying influential data and source of collinearity. New York, NY: Wiley

[4] Borg, W. R. \& Gall, M. D, (1983). Educational research: An introduction. New York: Longman

[5] Cheneau, Y, (1984). Towards new structures for the development of animal husbandry in Africa south of the Sahara. Rev. Sci. Tech. Off. Int. Epiz., 3(3): 621-627.

[6] Cheneau, Y. (1985). The organization of veterinary services in Africa. Rev. Sci. Tech. Off. Int. Epiz., 5(1): 107-154.

[7] Cook, P. \& Yuichiro, U (2003). "Privatization and Economic Growth in Developing Countries."The Journal of Development Studies, Vol.39, No.6, August 2003: 121-154.

[8] David,M. Sutton,C.(2004),Social Science:The Basics.Sage publications

[9] De Haan, C. \& Bekure, S. (1991). Animal health services in sub-Saharan Africa: initial experiences with alternative approaches. World Bank Technical Papers No. 134. Washington, DC, World Bank.

[10] Drazin, R and Rao, H (1999). Managerial power and succession: SBU manager of mutual funds. Organization studies, 20 (2), 169-196

[11]Easterly, W (2002) The Elusive Quest for Growth. Cambridge, Massachusetts: The MIT Press.

[12]FAO, (2012) Assessment of the Agriculture and Rural development sector in Eastern partnership Countries.

[13]FAO, (1994). Expert Consultation on Application of effective herd health and production programmes to increase livestock productivity in developing countries. 30 March-1 April1993, Rome.

[14]FAO/RLAC.(1992). Report of the round table on privatization of the veterinary services in Latin America and the Caribbean.12-14 November 1991, Santiago, Chile.

[15] FAO/RNEA, (1994).Study on privatization of veterinary services in the Near East region. Report of a meeting, 28-30, Cairo, Egypt.

[16] Fassi-Fehri, B.E.C. \& Bakkoury, M, (1995).Profile of the veterinary services in Morocco.Rome, FAO.

[17] Gathuma, J.,Chema,(2004).Kenya :the development of the private services and the role of the Kenya Veterinary Association.Rev sci Tech.2004 Apr;23(1):331-40

[18] Holden, S. \& Chema S, (1996).Delivery of animal health services: Kenya. Interim report/discussion document.Livestock in Development, Somerset.

[19] Hubl, K., Gathuma, J.M. and Kajume, J.K. (1998).Improved Delivery of Animal HealthServices in Kenya, Volume 1. Nairobi, Kenya: Ministry of Agriculture and Rural Development.

[20] Ilemobade, A. A. (1996). Privatization of veterinary services within the context of structural adjustment in Zimbabwe, Namibia and Ghana.Rome, FAO.

[21]Leonard, D.K,(2000) Africa's changing Markets for Health and Veterinary services:The new institutional issues.St Martins press.

[22]Leonard, D. K. (1987). The supply of veterinary services: Kenyan lessons. Agriculture.
[23] Admininstration \& Extension, 26: 219-236.

[24] Leonard, D.K. (1993). Structural reform of the veterinary profession in Africa and the new institutional economics. Development \& Change, 24: 227-267.

[25] McMillan,J \& Schumacher,S (1993),Research in education,a conceptual introduction.New york ,NY Harpercollins college publishers 1993.

[26] Mankiw, N. Gregory (2001), The Essentials of Economics. 2 edition. United States.

[27] McInerney, J. P., Howe, K.S. \& Schepers, J.A. (1992).A framework for the economic analysis of disease in farm livestock. Prev. Vet. Med., 13: 137-154.

[28] Megginson, William L., Robert C. Nash, \& Matthias van Randenborgh (1996), The Financial and Operating Performance of Newly Privatized Firms: An International Empirical Analysis. The Privatization Process.Ed. Terry L. Anderson and Peter J. Hill.United States of America: Rowman\& Littlefield Publishers, Inc., 115-153.

[29] Mehraban,A.B., Barker, T. \& Ward, D.E. (1996). Community-based animal health and production in Afghanistan - a delivery system.Paper presented at the Asian-Australian Animal Production Meeting, 13-18 October 1996, Makuhari, Japan.

[30] OIE (International Office of Epizootics). (1995). Recommendation of the OIE: appropriate privatization of veterinary practice in Africa. Rabat, Morocco.

[31]Poole, R. W. (1996), Privatization for Economic Development. The Privatization Process.Ed. Terry L. Anderson and Peter J. Hill. United States of America: Rowman\& Littlefield Publishers, Inc., 1-18.

[32] Schillhorn van Veen, T.W. \& de Haan, (1995).Trends in the organization and financing of livestock and animal health services. Prev. Vet. Med., 25: 225-240.

[33] Schreuder, B.E.C., Moll, H.A.J., Noorman, N., Halimi, C., Kroese, A.H. \& Wassink, G. (1995). A benefit-cost analysis of veterinary intervention in Afghanistan based on a livestock mortality study. Prev. Vet. Med., 26: 303 314.

[34] Sidahmed, A.E. (1995). Livestock development and rangelands management cluster: privatization of veterinary services in sub-Saharan Africa. Rome, International Fund for Agricultural Development (IFAD).

[35] Soto, Hernando de. (1996), The Missing Ingredient: What Poor Countries Will Need to Make Their Markets Work, The Privatization Process. Ed. Terry L. Anderson and Peter J. Hill. United States of America: Rowman\& Littlefield Publishers, Inc.,.19-24.

[36] Turkson, P.K, \& Brownie, C.F, (1999). Perceived constraints to privatization of delivery of veterinary services in Ghana. Tropical Animal Health and Production, 31, (2), 103-114.

[37] Umali, D., Feder, G. \& de Haan, C. (1992).The balance between public and private sector activities in the delivery of livestock services.World Bank Discussion Papers No. 63. Washington, DC, World Bank.

[38] Wamukoya, J. P. O., Gathuma, J. W. \& Mutiga, E. R. (1995).Spontaneous private veterinary practices evolution in Kenya since 1988. Rome, FAO.

[39] Wellman, J. C. \& Kruger, S. J. (2005). Research Methodology, $3^{\text {rd }}$ edition. Cape Town: Oxford University Press.

\section{Volume 6 Issue 12, December 2017}

\section{www.ijsr.net}

Licensed Under Creative Commons Attribution CC BY 


\section{International Journal of Science and Research (IJSR) \\ ISSN (Online): 2319-7064}

Index Copernicus Value (2016): 79.57 | Impact Factor (2015): 6.391

[40] William R.(2008). Multicollenearity. Retrived October 28, 2008, from http//www.nd.edu/ rwilliam/stats/111.pdf.

[41] World Bank (2002) The First Ten Years: Analysis and Lessons for Eastern Europe and the Former Soviet Union. Washington, D.C., The World Bank,

Volume 6 Issue 12, December 2017

www.ijsr.net 